\title{
Non-profit profits from animals
}

A Californian zoo much admired for the manner in which animals are displayed may have hit on an even more important secret — that of running a scientific institution without begging for public funds.

\section{San Diego}

THIs city is almost as well-known for its zoo as for anything else. By the $1950 \mathrm{~s}$, the San Diego zoo had won a generally envied reputation for the style in which its animals were exhibited. Relics of that period survive. But the zoo is now in the throes of remodelling itself so that its animals will be seen in simulations of their natural habitats, while the collection itself is being trimmed to accord with newer conservation doctrines. Even so, San Diego's chief claim on the attention of other zoos may be that it does all this without substantial subvention from public funds.

San Diego is more than a zoo-city, of course. It is the principal West Coast naval base of the United States (which is now mourning the first US land casualties of the Gulf War among marines from their base near the city). The city is also proud of the ninety or so biotechnology companies founded since Hybritech pitched its tent here in 1978. Then, a few miles further north, there is a clutch of distinguished research institutes which now almost dwarf the first of them, the Scripps Institution of Oceanography. (Chronologically, the Salk Institute came next, followed by the Scripps Clinic and Research Foundation.) The San Diego campus of the University of California is also working its way up the league table of federal grant recipients - last year it had reached sixth place. But the zoo is even more widely known, or at least more widely appreciated.

The zoo and its associated wildlife park is an astonishing enterprise, with an annual budget of more than $\$ 70$ million. Stung by San Diego's reputation, other city-centre zoos tend to remark on the size and splendour of its 100 -acre site, a mesa (where the car park is) scored by small canyons now being increasingly used as the sites of animal exhibits. But the reality is even better than it seems on paper. Originally on the outskirts of a small city, the zoo has seen one of the most rapidly growing cities in North America flow around it until it is no further from the city centre than are the principal art museums elsewhere.

San Diego's success as a zoological institution rests squarely on its willingness to be a part of the robust entrepreneurial traditions of North America. The zoo's hardcore support comes from the 180,000 families who have taken out membership of the Zoological Society of San Diego, which allows them open access (and privi- leged but paid access to special events). At $\$ 50$ a year, the zoo membership may be "the best buy in San Diego". There are also 80,000 youth members.

But out-of-town visitors are the hard core of the business. There are close on 2.5 million a year at the zoo, and more than half as many again at the wildlife park. As these things go, a day at the zoo is cheap at $\$ 10.75$, but San Diego reckons that what visitors buy (food and souvenirs) is even more valuable. And "the advertising is brilliant", one supporter says. Like any other business, the zoo changes advertising agents when that seems prudent.

The only regular contribution to costs from public funds is from a surcharge on property taxes levied by the city, which raises $\$ 2.5$ million a year, ostensibly for horticulture at the zoo (which can mean landscaping). San Diego is also always on the lookout for other sources of funds researchers apply for grants like other people, notably for work at the Center for Research on Endangered Species (which is also building up a substantial endowment fund). Just now, the zoo is embroiled in a row about its allegedly inattentive use of funds granted by the state of California for the retraining of zoo keepers.

The zoo's now-careful planning seems a far cry from its impulsive creation, in 1916 , by the migrant east-coast physician Dr Harry Wegeforth, who is said to have found some caged lions left over from an international trade exhibition, at which they had been used to entertain the crowds, and to have persuaded a local benefactress (name of Scripps) to give them a more fitting home in a dark concrete cave with natural barriers, rather than bars, to keep the people away from them.

Geography being what it is, the zoo has sought out from that start exotic species from South America and the eastern seaboard of Eurasia (no further away). Its tradition of providing natural settings for its animals (there are 3,500 at present) stems from the beginning, and is as much a sign that the zoo grew empirically as a measure of the generosity of its site. Its distinctiveness is the work of a handful of Wegeforth's successors, of whom the latest is David Rice, an architect turned zoo-designer, with a flair for turning the sides of mini-canyons into replicas of animals' habitats in miniature.

Thus San Diego already boasts of what it calls Tiger River, a steep track lined with tropical vegetation to simulate a rain forest (the canopy is not apparent) at the bottom of which is an enclosure for half a dozen tigers (the rare Siberian tiger lives elsewhere) which is perhaps 50 feet across, twice as long and also 100 feet high. The tigers, with their weight, have made a nice simulation of semi-arid India of their narrow patch. Rice is also somewhat surprised that a troupe of sun bears have so quickly worn through the green turf with which his enclosure had provided them.

Rice is now at work on an ambitious gorilla enclosure, intended as a slice of hillside that will be covered with appropriate vegetation. The site is now covered with a small army of people bent double with planting tools and with cranes intended to lift mature trees, with their roots encased in huge neat wooden boxes, into the holes that have been dug for them. Rice is about the only one on the site who is unperturbed that, after eighteen months, the whole enclosure is due to be occupied on 23 March.

These developments cannot but enhance San Diego's reputation as a showplace, but the zoo is also being nudged in other directions by the climate of the times. Taking animals from captivity, except when that is the best means of ensuring the survival of their species, is naturally frowned upon, which is why the zoo has concentrated so much attention on breeding in captivity. The general principle is that each species should be represented by enough members to give them a reasonable chance of maintaining themselves. There have been notable successes - San Diego is proud of the southeast Asian clouded leopards ( Neofelis nebulosa) it has bred, as well as of its black rhinos. There are also hopes that the time is fast approaching when it will be possible to begin releasing Californian condors bred in captivity to the wild, and even that the Andean condors which have grown up in the zoo will also be released.

Yet it has in common with the meanest zoos the trick of provoking the anthropocentric question why natural selection generated such a rich variety of magnificent animals that are nevertheless endangered. And it is doubtful whether even the splendid new exhibition areas planned will rid all visitors of the embarrassment that comes from looking at animals placed there for no other purpose than to be looked at.

John Maddox 